\title{
PENGARUH CAR, NPF, FDR, INFLASI DAN BI RATE TERHADAP PROFITABILITAS PERUSAHAAN PERBANKAN SYARIAH DI INDONESIA PERIODE 2014-2018
}

\author{
Nanda Nur Aini Fadillah \\ Universitas Negeri Surabaya \\ nuraininanda993@gmail.com \\ R. A. Sista Paramita \\ Universitas Negeri Surabaya \\ $\underline{\text { sistaparamita@unesa.ac.id }}$
}

\begin{abstract}
This study aims to analyze whether internal and external factors can affect Sharia banks' profitability in Indonesia because data is viewed data that the profitability of Sharia banks in Indonesia is increasing. However, Sharia banks' development decreases from the number of Sharia bank offices in Indonesia that remain even declining annually. The population used in this study is 14 Islamic commercial banks in Indonesia which the Financial Services Authority registers (OJK) rather than those filtered using specific criteria as stipulated during 2014-2018 in Indonesia and published financial statements for all periods of study and finally gained ten banks, this type of research is a quantitative causal. The results showed that one of the internal factors of the Capital Adequacy Ratio (CAR) had a positive influence over Sharia banking profitability (ROA) and other variables such as Non-Performing Finance (NPF), Financing of Debt Ratio (FDR), inflation, and BI Rate had no effect on Return On Asset (ROA).
\end{abstract}

Keywords: CAR, NPF, FDR, Inflasi, ROA.

\section{PENDAHULUAN}

Paket Kebijakan Deregulasi Perbankan 1988 disebut dengan Pakto 88 dikeluarkan oleh pemerintah dengan membuka peluang bidang usaha perbankan bertujuan untuk mendorong perluasan (liberalisasi struktur perbankan). Kendatipun lebih besar jumlah bank konvensional, dengan usaha perbankan yang bersifat daerah berlandaskan prinsip Islam mulai berkembang. Ide pembentukan bank berbasis syariah di Indonesia diawali pada tahun 1980, yang diuji cobakan memakai praktik dengan skala khusus diantaranya di Bandung (ITB) dan di Jakarta (ojk.go.id, 2017).

Semula UU No. 7 tahun 1992 ditinjau kembali sebagai UU No. 10 tahun 1998 di dalamnya menyimpan hikmah untuk bidang perbankan Indoneisa pasalnya pemerintah mendirikan bidang usaha perbankan berlandaskan kaidah syariah. Sesudah UU No. 10 tahun 1998 diterbitkan, terdapat Bank Muamalat Indonesia serta 80 BPR Syariah yang sudah berdiri. Andaikan diteliti faktor makro ekonomi, perluasan bank syariah di Indonesia memiliki suatu peluang besar. Pada 1998, pemerintah melangsungkan penyelesaian UU No. 7/1992 menjadi UU No. 10 Tahun 1998, secara gamblang tertulis bahwasannya terkandung dua jenis bank di Indonesia, ialah bentuk perbankan konvensional sertaperbankan syariah. Prospek tersebut disambut publik dengan antusias, sehingga terciptanya sejumlah Bank Islam lainnya, seperti Bank IFI, Bank Syariah Mandiri, Bank Niaga, Bank BTN, Bank Mega, Bank BRI, Bank Bukopin, dan sebagainya (ojk.go.id, 2017).

UU No.21 tahun 2008 mengenai Perbankan Syariah, UU No.19 tahun 2008 mengenai Surat Berharga Syariah Negara (sukuk), dan UU No.42 tahun 2009 mengenai Amandemen Ke-3 UU No.8 tahun 1983 mengenai PPN Barang serta Jasa merupakan perundang-undangan untuk menyampaikan ketegasan hukum dan memperluas suatu kegiatan pasar keuangan berbasis syariah. UU No. 21 Tahun 2008 mengenai Perbankan Syariah di Negara Indonesia diberlakukan pada 16 Juli 2008, akhirnya bidang perbankan berperinsip syariah mengalami perluasan sehingga dapat memegang tujuan dasar hukum yang seimbang untuk tetap melangsungkan perkembangannya (ojk.go.id, 2017). 
Nanda Nur Aini Fadillah \& R. A. Sista Paramita. Pengaruh CAR, NPF, FDR, Inflasi dan BI Rate terhadap Profitabilitas Perusahaan Perbankan Syariah di Indonesia Periode 2014-2018

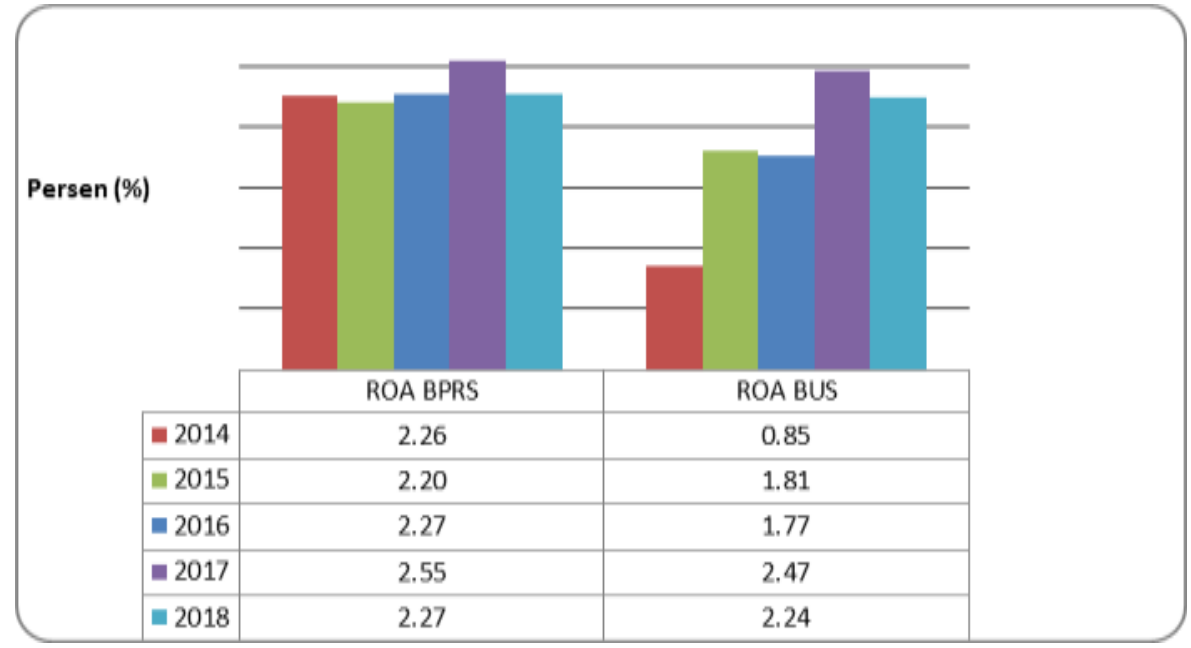

Sumber: ojk.go.id (2019, data diolah)

\section{Gambar 1. GRAFIK ROA (RETURN ON ASSET) BPRS DAN BUS DI INDONESIA PADA} TAHUN 2014-2018

Gambar 1 memperlihatkan bahwa perkembangan ROA ataupun laba bank syariah di Negara Indonesia mengalami penurunan serta persentasenya yang terus berubah-ubah setiap tahunnya. Diketahui juga persentase ROA Bank Pembiayaan Rakyat Syariah (BPRS) jauh di atas ROA Bank Umum Syariah (BUS) di Indonesia. Pernyataan tersebut bisa diketahui bahwasanya ada faktor-faktor yang harus diteliti lebih lanjut yang dapat memengaruhi penurunan laba BUS di Indonesia.

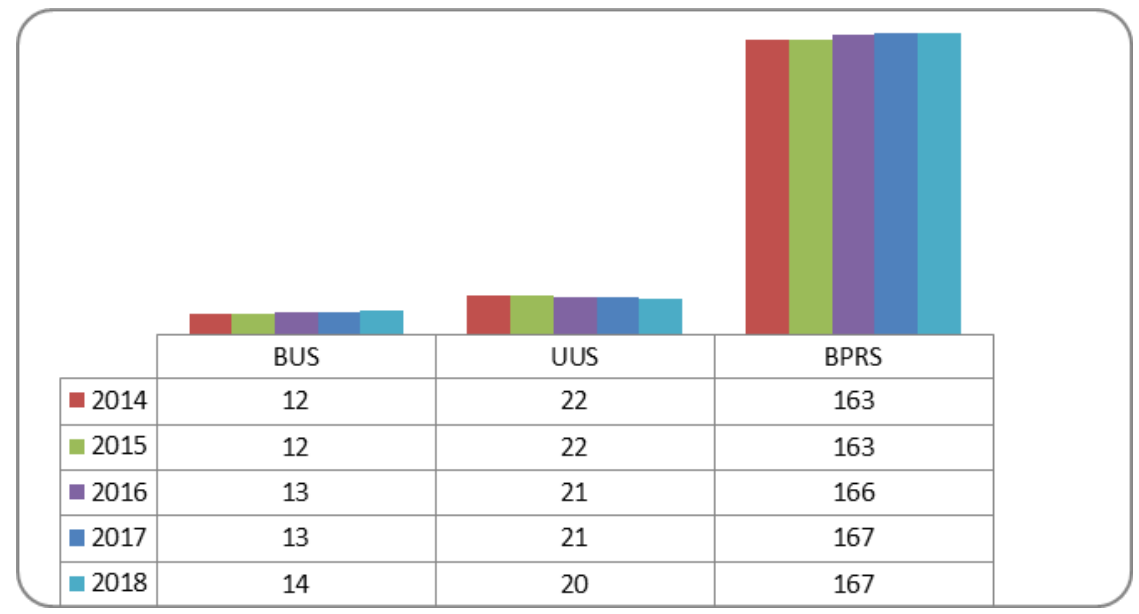

Sumber: ojk.go.id (2019, data diolah)

\section{Gambar 2. GRAFIK JUMLAH KANTOR BANK SYARIAH DI NEGARA INDONESIA PADA} TAHUN 2014-2018

Gambar 2 menunjukkan BUS yang terus bertambah. Sedangkan jumlah kantor BPRS juga terus meningkat, tetapi dari data di atas ada perbandingan yang cukup jauh antara jumlah BUS dengan BPRS. Dengan adanya data jumlah kantor ini menunjukkan bahwa ada sesuatu yang tidak berjalan sesuai yang diharapkan jika dibandingkan dengan data profitabilitas (ROA) sebelumnya, bahwa jumlah BUS yang semakin meningkat tetapi ROA Bank Umum Syariah mengalami penurunan. Dalam mengukur profitabilitas suatu perusahaan perbankan bisa menggunakan rasio-rasio keuangan (ojk.go.id, 2019).

Ketika menghitung profit industri perbankan bisa menggunakan sejumlah rasio keuangan. Hasil akhir yang didapat dari semua kebijakan keuangan dan keputusan bisa tercermin dalam operasional di mana terdapat sejumlah ratio yang bisa mengetahui suatu kombinasi dari suatu dampak likuiditas, manajemen asset terhadap hasil operasi disebut dengan ratio profitability (Brigham dan Houston, 
2010). Penelitian ini lebih mengacu pada ROA sebagai variabel dependen karena menurut (Avrita dan Pangestuti, 2016) Kinerja atau kesehatan perbankan merupakan cerminan dari profitabilitas, ROA dinilai lebih mewakili dalam pengukuran laba perbankan, karen Pada Bank Indonesia (BI) merujuk lebih kepada ROA daripada Return On Equity (ROE) diukur menggunakan asset di mana dana tersebut hampir semuanya dari tabungan nasabah. Faktor utama yang memengaruhi profitabilitas bank adalah manajemen permodalan (Capital Adquancy Ratio), manajemen umum, manajemen rentabilitas, dan manajemen likuiditas (Financing to Deposit Ratio) pada akhirnya memengaruhi terhadap pemasukan laba (ROA) perusahaan perbankan (Hakiim, 2018).

Selain itu ada faktor lain yang dapat memengaruhi ROA yaitu rasio bertujuan menghitung jumlah kredit yang dikategorikan bermasalah atas jumlah kredit kepemilikan bank disebut dengan rasio Not Performing Finance (NPF), sehingga banyaknya jumlah kredit bermasalah yang berakibat dengan hilangnya kesempatan dalam memperoleh pendapatan dari suatu pembiayaan yang diberikan sehingga bisa memengaruhi dalam memperoleh ROA (Yusuf, 2017).

Inflasi yakni faktor yang bisa memengaruhi profitabilitas (ROA) perbankan syariah, (Hananiah, 2015) inflasi bisa disebut suatu kenaikan beberapa harga yang terjadi dengan waktu terus menerus, menemukan bahwa makro ekonomi inflasi yang lebih akan memacu profitabilitas perbankan (Karim dkk, 2010).

Faktor yang terakhir yang bisa memengaruhi ROA yaitu suku bunga kebijakan yang bisa mencerminkan suatu sikap atau stance dalam kebijakan moneter yang dipatenkan oleh BI dan diberitahukan ke khalayak ramai atau disebut dengan BI Rate (bi.go.id, 2017).Perkembangan perbankan dapat terganggu dengan pertumbuhan tingkat suku bunga yang tidak wajar secarra langsung (Kusuma, 2018).

Sejumlah penelitian yang dilakukan sebelumnyadengan tujuan agar bisa mengetahui dampak dari CAR, NPF, FDR, inflasi, serta BI Rate atas laba (ROA) BUS, di antaranya yaitu penelitian Abduh \& Idrees (2013) yang menunjukkan hasil bahwa CAR berdampak signifikan negatif atas ROA sedangkan Inflasi berdampak signifikan atas ROA.Penelitian oleh Yusuf (2017) menyatakan bahwa CAR, NPF, dan FDR berdampak signifikan positif atas ROA.Penelitian Aliyu \& Yusof (2016) memperlihatkan hasil bahwa Inflasi berdampak signifikan negatif atas ROA.Penelitian Sumarlin (2016) menyatakan hasil bahwa CAR, dan NPF berdampak signifikan negatif atas ROA, sedangkan FDR dan inflasi berdampak signifikan positif atas ROA.

Hal tersebut membuktikan bahwa hasil penelitian tentang pengaruh CAR, NPF, FDR, Inflasi dan BI raten mengarah tidak konsisten atau berbeda antara beberapa penelitian. Penelitian ini bertujuan untuk menganalisis pengaruh CAR, NPF, FDR, Inflasi dan BI Rate terhadap Profitabilitas (ROA) perusahaan perbankan di Indonesia.

\section{KAJIAN PUSTAKA DAN PENGEMBANGAN HIPOTESIS}

\section{Teori Sinyal (Signalling Theory)}

Menurut Fahmi dan Hadi (2009:108), Signalling Theory merupakan teori menujukkan kondisi perusahaan.Untuk menggambarkan suatu prilaku pada saat dua pihak mempunyai akses atas suatu informasi yang berbeda merupakan tujuan teori persinyalan.Pelaku pasar sebelumnya menginterprestasikan dan membedah suatu berita yang disebut suatu signal baik atau signal buruk pada saat diumumkannya berita tersebut (Jogiyanto, 2010:392). Pada teori ini, adapun motivasi manajemen menyajikan informasi keuangan diharapkan dapat memberikan signal kemakmuran kepada pemilik ataupun pemegang saham. Publikasi laporan keuangan tahunan yang disajikan oleh perusahaan akan dapat memberikan signal pertumbuhan deviden maupun perkembangan harga saham perusahaan (Kusuma, 2016). Teori ini juga mengemukakan tentang bagaimana seharusnya sebuah perusahaan memberikan sinyal kepada pengguna laporan keuangan. Sinyal ini berupa informasi 
Nanda Nur Aini Fadillah \& R. A. Sista Paramita. Pengaruh CAR, NPF, FDR, Inflasi dan BI Rate terhadap Profitabilitas Perusahaan Perbankan Syariah di Indonesia Periode 2014-2018

mengenai apa yang sudah dilakukan oleh manajemen untuk merealisasikan keinginan pemilik (Jogiyanto, 2000).

\section{Teori Keagenan (Agency Theory)}

Hubungan keagenan mengakibatkan dua permasalahan yaitu terjadinya informasi asimetris, di mana manajemen secara umum memiliki lebih banyak informasi mengenai posisi keuangan daripada pemilik, kemudian terjadinya konflik kepentingan akibat ketidak samaan tujuan (Meiser dkk, 2006). Dalam upaya untuk mengatasi masalah keagenan tersebut maka timbulah biaya keagenan seperti monitoring cost, bonding cost, dan residual cost. Untuk mengurangi biaya-biaya tersebut, diperlukannya suatu alat control yang dapat mengurangi risiko terjadinya asimetris informasi. Alat control yang dapat digunakan para stakeholders adalah laporan tahunan. Laporan tahunan pada dasarnya merupakan sarana transparansi dari akuntabilitas manajer kepada pemilik modal (Bernadi dkk, 2009).

\section{Kinerja Perusahaan}

Untuk mengetahui prestasi yang dicapai perusahaan perlu dilakukan penilaian terhadap kinerja perusahaan dalam kurun waktu tertentu. Penilaian kinerja perusahaan dapat diketahui melalui perhitungan rasio financial dari semua laporan keuangan yang disajikan perusahaan.penelitian ini menggunakan rasio ROA. Return On total Asset adalah rasio perbandingan antara laba setelah pajak dengan total aktiva yang digunakan untuk mengukur kemampuan perusahaan dalam menghasilkan laba atas aktiva yang dipergunakan pada periode tertentu. Indikasinya bila ROA perusahaan dari tahun ke tahun semakin naik, maka perusahaan semakin efisien dalam mengelolah bisnisnya, begitu juga sebaliknya (Purwohandoko dkk, 2014:54). Rasio dari beberapa ratio profitability lainnya yang terdapat didalam suatu analisis laporan keuangan, umumnya tidak jarang digunakan karena sanggup memperlihatkan apakah perusahaan mampu untuk meraih suatu laba pada masa lampau lalu diproyeksikan di masa selanjutnya, rasio ini ialah Return on Asset (Yusuf, 2017). Rasio ROA digunakan untuk mengukur kemampuan manajemen bank dalam memperoleh keuntungan secara keseluruhan, batas minimum yang ditentukan oleh Bank Indonesia adalah 1\%. Jika suatu bank memiliki nilai ROA si atas $1 \%$, maka bank tersebut dapat dikatakan produktif dalam mengelolah aktiva sehingga menghasilkan laba dan tergolong dalam kondisi sehat (Daniel\&Asandimitra, 2016). Rumus perubahannya dapat dilihat di rumus (1) (Purwohandoko dkk, 2014).

ROA $=\frac{\text { Laba SetelahPajak }}{\text { Total Asset }} \times 100 \%$.

\section{Capital Adquancy Ratio (CAR)}

Capital Adquancy Ratio merupakan rasio yang mempunyai tujuan menilai kecukupan equity yang berasal dari perbankan guna mendorong aktiva yang mengandung ataupun menyebabkan risiko. Rumus perubahannya dapat dilihat di rumus (2) (Ruslim, 2012).

$$
\text { CAR }=\frac{\text { Modal Bank }}{\text { Total ATMR }} \times 100 \% \text {. }
$$

Modal Bank : Modal yang diperoleh dari pemegang saham bank tersebut ATMR : : Aset Tertimbang Menurut Risiko

\section{Net Performing Finance (NPF)}

Risiko keterbatasanseorang nasabah atau lebih dalammembayar suatu pinjaman yang sebelumnya sudah diterima dari bank syariah beserta imbalandandalam kurun waktu yang sudahdisepakati sebelumnya disebut Non Performing Finance (Mahmuda dan Harjanti, 2016:137).Menurut Kinanti \&Purwohandoko (2018) Pembiayaan (NPF) adalah pembiayaan bermasalah yang terdiri dari pembiayaan dengan klasifikasi kurang lancar, dan diragukan.Rumus perubahannya dapat dilihat di rumus (3) (Yusuf, 2017).

NPF $=\frac{\text { Jumlah PembiayaanBe }(\text { masalah }}{\text { Total Pembiayaan }} \times 100 \%$. 


\section{Finance to Deposit Ratio (FDR)}

Suatu rasio dengan tujuan melakukan pengukuran likuiditas bank caranyamengembalikanuang yang ditarik deposan serta mengandalkan kredit yang telah diterimadan merupakan sumber dari likuidasinya adalah Financing to Deposit Ratio (Arthesa, 2009). Menurut Kinanti \& Purwohandoko (2018), rasio pembiayaan untuk deposit adalah ukuran alat untuk mengukur volume pembiayaan rasio sehingga rasio FDR ini adapat menunjukkan kesehatan bank dalam memberikan pembiayaan. Rumus perubahannya dapat dilihat di rumus (4) (Yusuf, 2017).

$$
\text { FDR }=\frac{\text { Total Pembiayaan }}{\text { Total Dana Pihak Ketiga }} x 100 \% \text {. }
$$

\section{Inflasi}

Menurut BI kestabilan suatu inflasi adalah faktor utama yang bisa memberikan dampak atas suatu pegembangan ekonomi dalam Negara yang bisa memberikan kemakmuran bagi kelangsungan hidup rakyat (Hananiah, 2015). Rumus perubahannya dapat dilihat di rumus (5) (Sartika, 2017).

$$
\text { Inflasi }=\frac{\text { IHK } t-I H K t-1}{\text { IHK } t-1}
$$

Keterangan:

IHK $_{\mathrm{t}}$ : Indeks Harga Konsumen Periode ${ }_{\mathrm{t}}$ $\mathrm{IHK}_{\mathrm{t}-1}:$ Indeks Harga Konsumen Periode ${ }_{\mathrm{t}-1}$

\section{BI Rate}

Suku bunga dari kebijakan yang bisa dicerminkanmelalui sikap atau stance kebijakan moneter kepada publik yaitu BI Rate (bi.go.id, 2009). Menurut Amin (2012), suku bunga ialah tingkat bunga yang telah diputuskan oleh Bank Indonesia dan menjadi acuan selaku tingkat bunga standard oleh bank pemerintah dan bank swasta. Penelitian ini perhitungannya memakai nilai BI Rate asli setiap bulannya dari tahun 2016 sampai dengan tahun 2019.

\section{Hubungan antar Variabel}

Menurut Manuba (2011), CAR merupakan rasio keuangan yang berkaitan dengan permodalan perbankan di mana besarnya modal suatu bank akan berpengaruh pada mampu atau tidaknya suatu bank secara efisien menjalankan kegiatannya. Dalam teori keagenan alat kontrol bagi perusahaan dan investor ialah laporan keuangan tahunan yang disajikan oleh manajemen perusahaan, agar tidak ada informasi asimetris maka informasi yang diterima oleh investor lebih jelas terkait naik turunnya tingkat rasio perbankan serta laba perbankan tersebut. CAR mencerminkan modal perusahaan,semakin besar CAR maka semakin besar kesempatan bank dalam menghasilkan laba karena dengan modal yang besar manajemen bank dapat leluasa dalam menempatkan dananya kedalam aktivitas investasi yang menguntungkan (Wibowo \& Syaichu, 2013) yang artinya saat nilai CAR tinggi maka profitabilitas (ROA) perbankan akan mengalami kenaikan, begitu juga sebaliknya.

H1: CAR berpengaruh positif terhadap ROA periode 2014-2018.

Menurut Mahmuda dan Harjanti (2016:137), Non Performing Finance (NPF) adalah risiko akibat ketidakmampuan nasabah mengembalikan jumlah pinjaman yang diterima dari bank syariah beserta imbalannya sesuai dengan jangka waktu yang telah ditentukan. Informasi mengenai nilai rasio-rasio dalam perbankan telah tercantum dalam laporan keuangan tahunan, dalam signalling theory menyatakan terdapat kabar baik dan buruk. Kabar baik ialah di mana nilai rasio NPF semakin turun yang artinya profitabilitas perbankan syariah tersebut akan mengalami kenaikan, maka investor dapat mengambil keputusan untuk memilih menginvestasikan dananya ke perusahaan perbankan yang memiliki nilai NPF semakin turun. Hal ini didukung oleh penelitian Syah (2015), dan Kusuma (2018) yang menyatakan bahwa NPF berpengaruh negatif terhadap ROA, karena apabila nilai rasio NPF semakintinggi maka tingkat profitabilitas (ROA) perbankan syariah akan mengalami penurunan. 
Nanda Nur Aini Fadillah \& R. A. Sista Paramita. Pengaruh CAR, NPF, FDR, Inflasi dan BI Rate terhadap Profitabilitas Perusahaan Perbankan Syariah di Indonesia Periode 2014-2018

H2: NPF berpengaruh negatif terhadap ROA periode 2014-2018.

Rasio ini menggambarkan kemampuan bank membayar kembali penarikan yang dilakukan nasabah deposan dengan mengandalkan kredit yang diberikan sebagai sumber likuiditasnya (Hakiim, 2018). Semakin tinggi nilai rasio FDR maka memberikan indikasi rendahnya kemampuan likuditas bank tersebut, hal ini sebagai akibat jumlah dana yang diperlukan untuk membiayai kredit semakin besar (Rivai dkk, 2007:718). Semakin tinggi FDR dalam batas tertentu, maka semakin meningkat pula laba bank dengan asumsi bank menyalurkan dananya untuk pembiayaan yang efektif (Yusuf, 2017). Penelitian yang dilakukan oleh Yusuf (2017), dan Simatupang A dan Franzlay (2016) memperoleh hasil FDR berpengaruh positif terhadap ROA, jika nilai rasio FDR semakin tinggi maka profitabilitas (ROA) perbankan syariah akan mengalami kenaikan, begitu juga sebaliknya.

H3: FDR berpengaruh positif terhadap ROA periode 2014-2018.

Inflasi adalah suatu keadaan di mana harga-harga akan suatu barang mengalami kenaikan dalam kurun waktu tertentu dalam suatu wilayah perekonomian, inflasi memiliki dampak positif dan dampak negatif tergantung parah atau tidaknya inflasi (Sumarlin, 2016). Berdasarkan signalling theory, informasi yang dipublikasikan sebagai suatu pengumuman data akan memberikan sinyal bagi investor dalam keputusan berinvestasi. Informasi tersbut sebagai sinyal baik (good news) ataupun sinyal buruk (bad news) (Jogiyanto, 2010). Ali dkk (2011) menyatakan bahwa inflasi berpengaruh signifikan positif terhadap profitablitas pada bank umum di Pakistan, karena apabila tingkat inflasi semakin tinggi maka profitabilitas perbankan syariah juga mengalami kenaikan.

H4: Inflasi berpengaruh positif terhadap ROA periode 2014-2018.

Menurut Syah (2018), BI rate adalah suku bunga kebijakan yang mencerminkan sikap atau stance kebijakan moneter yang ditetapkan oleh Bank Indonesia dan diumumkan oleh Dewan Gubernur Bank Indonesia kepada publik. Menurut penelitian yang telah dilakukan oleh Syah (2018) yang menyatakan bahwa BI rate berpengaruh signifikan negatif terhadap ROA, pada signalling theory menjelaskan bahwa informasi yang dipublikasikan perusahaan sebagai pengumuman memberikan sinyal bagi investor untuk mengambil keputusan dalam berinvestasi. Ketika BI rate naik, maka akan diikuti oleh naiknya suku bunga deposito yang berakibat langsung terhadap penurunan sumber dana pihak ketiga bank syariah. penurunan dana pihak ketiga sebagai akibat pemindahan dana masyarakat ke bank konvensional untuk mendapatkan imbalan bunga yang lebih tinggi (Karim, 2006). Hal ini didukung oleh penelitian yang dilakukan oleh Syah (2015) yang menyatakan bahwa Inflasi berpengaruh negatif terhadap profitabilitas perbankan syariah. Karena jika tingkat suku bunga naik maka profitabilitas perbankan syariah akan mengalami penurunan, begitu juga sebaliknya.

H5: BI Rate berpengaruh negatif terhadap ROA periode 2014-2018.

\section{METODE PENELITIAN}

Penelitian ini merupakan penelitian kausal kuantitatif, karena memiliki fungsi untuk mendapatkan hubungan sebab dan akibat untuk mencari bukti ada tidaknya pengaruh hubungan variabel independen, yaitu Capital Adquancy Ratio (CAR), Non Performing Finance (NPF), Financing to Deposit Ratio (FDR), Inflasi dan BI Rate terhadap variabel dependen yaitu Profitabilitas (ROA) Bank umum syariah di Indonesia. Penelitian ini menggunakan data sekunder, data yang digunakan dalam penelitian ini merupakan data laporan keuangan tahunan perusahaan perbankan syariah periode 20142018. Data dalam penelitian ini diambil dari website resmi masing-masing bank, dan website Bank Indonesia yaitu www.bi.go.id. Populasi penelitian seluruh Bank Umum Syariah (BUS) di Indonesia, adapun yang menjadi sampel dalam penelitian ini adalah yang memenuhi kriteria yaitu BUS di Indonesia yang berdiri sejak 2014-2018 dan BUS yang mempublikasikan laporan keuangan tahunan periode 2014-2018 di website masing-masing bank. 
Sehingga sampel penelitian yang didapat berjumlah 50 data (10 Bank Umum Syariah x 5 tahun). Namun terdapat 20 data yang masuk kedalam data outlier, sehingga data tersebut harus dihilangkan, jadi data yang digunakan berjumlah 30 . Jenis data menggunakan data kuantitatif dengan teknik pengumpulan data purposive sampling karena teknik ini adalah teknik pengambilan sampel dengan tidak berdasarkan random, daerah atau strata, melainkan berdasarkan adanya pertimbangan yang berfokus pada tujuan tertentu (Arikunto:2006). Menurut Sugiyono (2010) purposive sampling adalah teknik yang menentukan sampel penelitian dengan beberapa pertimbangan tertentu yang bertujuan agar data yang diperoleh nantinya bisa lebih representatif. Uji asumsi klasik terdiri dari Uji multikolinieritas dengan melihat nilai tolerance dan VIF. Penelitian ini menggunakan uji run test untuk mendeteksi autokorelasi, dengan nilai signifikansi lebih dari 0,05. Uji heteroskedastisitas menggunakan uji glejser, uji normalitas menggunakan analisis grafik normal probabilityplot dan uji Kolmogrov-Smirnov (KS). Uji liniearitas dilakukan dengan menggunakan uji Lagrrange Multiplier.Teknik analisis data yang digunakan adalah analisis regresi linear berganda menggunakan bantuan Statistical Program For Science (SPSS) 22 .Uji hipotesis dilakukan dengan menggunakan uji terdiri dari uji statistik t, uji statistik f, dan koefisien determinasi (Ghozali, 2016:99).

\section{HASIL DAN PEMBAHASAN}

\section{Statistik Deskriptif}

Untuk memperlihatkan gambaran secara umum variabel terikat dan variabel bebas, digunakan uji statistik deskriptif yang dapat dilihat di tabel 1. Pada variabel ROA, nilai terendah yaitu sebesar ,1123 nilai tertinggi sebesar 0,0827, mean sebesar 0,006004, dan nilai Std. Deviasi sebesar 0,0243051. Std. Deviasi variabel ROA mempunyai keberagaman bervariasi dikarenakan Std. Deviasi > mean. Kemudian variabel CAR, nilai terendah yaitu sebesar 0,1151 , nilai tertinggi sebesar 0,3670 , mean sebesar 0,189112, dan nilai Std. Deviasi sebesar0,0570533. Std. Deviasi variabel CAR tidak mempunyai keberagaman data bervariasi dikarenakan Std. Deviasi <mean.

Pada variabel NPF, nilai terendah yaitu sebesar 0,0001 , nilai tertinggi sebesar 0,1252 , mean sebesar 0,036432, dan nilai Std. Deviasi sebesar 0,0250966. Std. Deviasi variabel NPFtidak mempunyai keberagaman data bervariasi dikarenakan Std. Deviasi < mean. Kemudian variabel FDR, nilai terendah yaitu sebesar 0,2955, nilai tertinggi sebesar 1,1416, mean sebesar 0,848864, dan nilai Std. Deviasi sebesar 0,1489922. Std. Deviasi variabel inflasi tidak mempunyai keberagaman data bervariasi dikarenakan Std. Deviasi <mean.

\section{Tabel 1. STATISTIK DESKRIPTIF}

\begin{tabular}{llrrrr}
\hline Variabel & N & \multicolumn{1}{c}{ Minimum } & Maximum & Mean & \multicolumn{1}{c}{ Std. Deviation } \\
\hline CAR & 50 &, 1151 &, 3670 &, 189112 &, 0570533 \\
NPF & 50 &, 0001 &, 1252 &, 036432 &, 0250966 \\
FDR & 50 &, 2955 & 1,1416 &, 848864 &, 1489922 \\
INLASI & 50 &, 0302 &, 0386 &, 042940 &, 0206375 \\
BI RATE & 50 &, 0456 &, 0817 &, 063460 &, 0133743 \\
ROA & 50 &,- 1123 &, 0827 &, 006004 &, 0243051 \\
Valid N (listwise) & 50 & & & &
\end{tabular}

Sumber: Hasil dari Output SPSS (2020, data diolah)

Pada variabel inflasi, nilai terendah yaitu sebesar 0,0302 , nilai tertinggi sebesar 0,0386 , mean sebesar 0,042940, dan nilai Std. Deviasi sebesar 0,0206375. Std. Deviasi variabel inflasi tidak mempunyai keberagaman data bervariasi dikarenakan Std. Deviasi<mean. Kemudian variabel BI Rate, nilai terendah yaitusebesar0,0456, nilai tertinggi sebesar 0,0817, meansebesar 0,063460, dan nilai Std. Deviasi sebesar 0,0133743. Std. Deviasi variabel BI Ratetidak mempunyai keberagaman data bervariasi dikarenakan Std. Deviasi <mean. 
Nanda Nur Aini Fadillah \& R. A. Sista Paramita. Pengaruh CAR, NPF, FDR, Inflasi dan BI Rate terhadap Profitabilitas Perusahaan Perbankan Syariah di Indonesia Periode 2014-2018

\section{Hasil Uji Asumsi Klasik}

Berdasarkan tabel 2, hasil uji normalitas dengan Kolmogorov-Smirnov (K-S) setiap variabel menunjukkan Asymp. Sig. 2-tailed lebih dari 0,05 maka data residual telah terdistribusi normal. Pada tabel 2, uji heteroskedastisitas menggunakan uji Glejer. Dari hasil SPPS diketahui nilai sgnifikansi setiap variabel lebih dari 0,05 sehingga model regresi tidak mengalami heteroskedastisitas. Tabel 2 menunjukkan hasil uji multikolinieritas, yaitu nilainya leih besar atau sama dengan nilai 0,10 . Kemudian, pada nilai VIF sudah memenuhi kriteria yaitu memberikan hasil nilai yang kurang dari 10 . Maka tidak adanya korelasi antar variabel dan model regresi tidak terdapat multikolinieritas

Kemudian hasil pengujian autokorelasi pada tabel 2 dengan Durbin-Watson, hasilnya telah ditemukan du senilai 1,8326 serta nilai dw senilai 1,659. NilaiD-W berada di antara du dan 4-du yaitu 1,8326 < $1,659<2,1674$ memberikan hasil bahwa terdapat autokorelasi positif, maka dilakukan alternatif uji Runs test untuk memastikan bahwa nilai Asymp. Sig. 2-tailed lebih dari 0,05dan diketahui hasilnya sebesar 0,853 yang artinya bahwa tidak terjadi autokorelasi pada penelitian ini. Hasil pengujian linieritas pada tabel 2 dengan uji lagrange multiplier dari nilai $R^{2}$ yaitu 0,022 dengan $n=30$, sehingga nilai $c^{2}$ hitung sebesar 0,66 . Kemudian besarnya nilai $c^{2}$ tabel dengan taraf kepercayaan 0,05 adalah 36,42. Nilai $\mathrm{c}^{2}$ hitung lebih kecil daric ${ }^{2}$ tabel $(0,66<36,42)$ maka model yang tepat untuk digunakan adalah model linier. Berdasarkan tabel 3, diperoleh model persamaan (6).

$\mathrm{ROA}=0,012+0,060 \mathrm{CAR}+\mathrm{e}$

Tabel 2.

HASIL UJI ASUMSI KLASIK

\begin{tabular}{|c|c|c|c|c|c|c|}
\hline \multirow[t]{2}{*}{ Variabel } & \multirow{2}{*}{$\begin{array}{l}\text { Normalitas } \\
\text { Sig. }\end{array}$} & \multirow{2}{*}{$\begin{array}{l}\text { Autokorelasi } \\
\text { Run Test }\end{array}$} & \multicolumn{2}{|c|}{ Multikolonearitas } & \multirow{2}{*}{$\begin{array}{c}\text { Heterokedastisitas } \\
\text { Sig. }\end{array}$} & \multirow[t]{2}{*}{ Linearitas } \\
\hline & & & Tolerance & $V I F$ & & \\
\hline & 0,200 & 0,853 & & & & $0,66<36,42$ \\
\hline CAR & & & 0,911 & 1,097 & 0,798 & \\
\hline NPF & & & 0,810 & 1,235 & 0,286 & \\
\hline FDR & & & 0,905 & 1,105 & 0,139 & \\
\hline Inflasi & & & 0,920 & 1,087 & 0,381 & \\
\hline BI Rate & & & 0,695 & 1,439 & 0,068 & \\
\hline
\end{tabular}

Sumber: Hasil dari Output SPSS (2020, data diolah)

Tabel 3

HASIL UJI HIPOTESIS

\begin{tabular}{lcccccc}
\hline & B & Std. Error & T & Sig. & R & Adjusted R Square \\
\hline (Constant) &,- 012 &, 011 & $-1,177$ &, 251 & & \\
CAR &, 060 &, 023 & 2,653 &, 014 & & \\
NPF &,- 092 &, 056 & $-1,646$ &, 113 & & \\
FDR &, 007 &, 009 &, 803 &, 430 & & \\
Inflasi &, 000 &, 083 &, 005 &, 996 & & \\
BI Rate &, 074 &, 078 &, 945 &, 354 & & \\
Uji Statistik F & & & & 0,043 & & \\
Uji Koefisien & & & & & 0,363 & 0,230 \\
Determinasi & & & & & &
\end{tabular}

Sumber: Hasil dari Output SPSS (2020, data diolah)

Dari kelima variabel penelitian terdapat satu variabel yang memberikan pengaruh signifikan terhadap variabel dependen yaitu variabel CAR $\left(\mathrm{X}_{1}\right)$. Berdasarkan persamaan regresi berganda dapat dijelaskan bahwa nilai konstanta sebesar - 0,012 berarti bahwa jika nilai CAR konstan, atau sama dengan nol, maka nilai ROA adalah -0,012, sedangkan CAR yang memiliki nilai 2,653 berarti bahwa jika nilai CAR meningkat 1 satuan, maka nilai ROA akan mengalami kenaikan sebesar 2,653. Hasil pengujian uji F pada tabel 3, memberikan hasil signifikansi F hitung sebesar 0,043 lebih kecil dari 0,05. Artinya 
variabel independen yaitu CAR, NPF, FDR, Inflasi dan BI Rate secara bersama-sama berpengaruh terhadap variabel dependen yaitu Return On Asset (ROA).

Berdasarkan tabel 3, bahwa nilai t hitung variabel CAR senilai 2,653 dengan signifikansi 0,014, sehingga CAR memengaruhi ROA. Besarnya nilai t hitung variabel NPF senilai -1,646 dengan signifikansi 0,113, sehingga NPF tidak memengaruhi ROA. Nilai t hitung variabel FDR0,803 dengan signifikansi 0,430 , sehingga FDR tidak memengaruhi ROA. Nilai t hitung variabel Inflasi senilai 0,005 dengan signifikansi 0,996, sehingga Inflasi tidak memengaruhi ROA. Nilai t hitung variabel BI Rate senilai 0,945 dengan signifikansi 0,354, sehingga BI Rate tidak memengaruhi ROA.

Berdasarkan tabel 3, hasil pengujian koefisien determinasi memberikan output bahwa besarnya adjusted $R^{2}$ sebesar 0,230 atau 20,3\% maka variabel independen yaitu CAR, NPF, FDR, Inflasi dan BI Rate dalam penelitian mampu menjelaskan variabel dependen yaitu Return On Asset (ROA) sebesar 20,3\%, kemudian 79,7\% dijelaskan oleh variabel lain yang tidak digunakan dalam penelitian ini seperti variabel Thrid party funds (Nuriyah, Endri dan Yasid, 2018) dan Gross Domestic Product (GDP), securities (Aliyu dan Yusof, 2016). Nilai R koefisien korelasi sebesar 0,363, sehingga kekuatan hubungan antara variabel independen terhadap variabel dependen sebesar 36,3\%.

\section{Pengaruh CAR terhadap ROA}

Berdasarkan hasil analisis membuktikan bahwa (CAR) mempunyai dampak signifikasi positif atas Profitabilitas (ROA) perbankan syariah tahun 2014 hingga 2018.Tingkat CAR yang tinggi akan meningkatkan ROA perusahaan. Rasio bertujuan menilai besarnya equity telah cukup untuk mendorong kebutuhannya disebut CAR (Ervani, 2010).

CAR merupakan satu dari faktor lainnya yangberperan dalam perluasan suatu usaha yang dapat menanggung risiko defisit, jika nilai CAR tinggi maka semakin besar kemampuan bank dalammemperoleh risiko suatu kredit atau aktiva produktif ialah modal (Ruslim, 2012). Hal ini sejalan dengan suatu ketentuan tingkatkesehatan bank serta kalkulasi rasio modal minimal yang disebut CAR tercantum dalam Peraturan BI No.13/PBI/2011. Penelitian ini mendukung dalam pernyataan Signalling Theory bahwa setiap laporan yang dipublikasikan merupakan pengumuman tentang data atau informasi perusahaan yang didalamnya terdapat berita baik dan buruk dengan tujuan untuk dijadikan salah satu pertimbangan dalam menentukan pilihan maupun investasi.

\section{Pengaruh NPF terhadap ROA}

Berdasarkan hasil analisis membuktikan bahwa (NPF) tidak mempunyai dampak significant atas laba (ROA) perbankan syariah tahun 2014 hingga 2018. Karena pembiayaan yang diberikan olehBUS masih belum optimal masih terhambat saat meneruskan pembiayaan kepada konsumen, sehingga risiko pembiayaan macet sangat kecil dan tidak memiliki dampak atas laba BUS. Output riset ini tidak didukung oleh teori persinyalan di mana, NPF adalah faktor yang bisa memengaruhi laba perbankan berbasis syariah.

Dalam teori NPF signifikan negatif atas ROA, jika value NPF naik maka laba perbankan syariah akan menurun. Pembiayaan yang dikategorikan bermasalah (NPF) dalam bank konvensional disebut kredit macet (NPL) menunjukkan NPF tidak berpengaruh terhadap laba jangka pendek atau jangka panjang (Hananiah, 2015).

\section{Pengaruh FDR terhadap ROA}

Berdasarkan hasil analisis membuktikan (FDR) tidak mempunyai dampak significant atas laba (ROA) perbankan syariahtahun 2014 hingga 2018. Dikarenakan BUS dalam mendistribusikan pembiayaan masih belum efektif serta optimal. Disebabkan oleh naiknya suatu pembiayaan yang dikategorikan tidak lancar seiring dengan jumlah pembiayaan yang diberikan oleh perbankan (Widyaningrum\& Septriani, 2015). 
Penyaluran dana yang tidak efektif disebabkan oleh beberapa masalah. Masalah itu diantaranya seperti penilaian calon nasabah yang kurang tepat, terjadi musibah yang tidak diduga, sehingga beban yang ditanggung oleh nasabah juga akan ditanggung bank syariah. Namun pada dasarnya perbankan syariah menekankan prinsip bagi hasil, di mana laba bersih tersebut akan dibagi dua dari usaha atau pendanaandari bank. Laba tersebut akan dibagi secara dua pihak untuk nasabah serta bank syariah itu sendiri. Namun apabila terjadi hal yang sebaliknya, pada saat nasabah mengalami kerugian dalam usahanya yang mengakibatkan tidak bisa membayar kredit, maka kerugian tersebut akan dibagi secara dua pihak.

\section{Pengaruh Inflasi terhadap ROA.}

Berdasarkan hasil analisis membuktikan bahwa (Inflasi) tidak mempunyai dampak significant atas Profitabilitas (ROA) perbankan syariah tahun 2014 hingga 2018. Walaupun inflasi tinggi tetapi tidak memengaruhi laba perusahaan perbankan syariah di Indonesia. Karena tingginya harga barang dicerminkan oleh tingginya inflasi yang bisa menurunkan nilai peredaran uang, namum suatu pengaruh yang negatif dari inflasi masih belum terlihat signifikan ditingkat 5\% hal tersebut bisa diartikan dengan adanya inflasi tidak akan menurunkan nilai deposito atau simpanan di bank syariah (Wibowo dan Syaichu, 2016).

Jika terjadinya inflasi, perbankan akan menarik perhatian masyarakat dengan menaikan suku bunga dengan tujuan masyarakat mau menabung uangnya di bank. Dengan begitu masyarakat akan tertarik dengan bank konvensional yangmenawarkan suku bunga yang palingtinggi daripada bank syariah yang menerapkan bagi hasil. Menurut munir (2018) inflasi tidak berpengaruh atas ROA, walaupun inflasi mengalami peningkatan tidak akan menurunkan laba yang dimiliki oleh perbankan syariah dan kebalikannya. Jadi, inflasi bukanlah penyebab naik atau turunnya laba (ROA) BUS.

\section{Pengaruh BI Rate terhadap ROA}

Berdasarkan hasil analisis tersebut, membuktikan BI Rate tidak mempunyai dampak significant atas laba (ROA) perbankan syariah tahun 2014 hingga 2018. Karena nasabah perbankan syariah merupakan nasabah yang cenderung mengedapankan prinsip atau aturan di dalam syariah Islam melarang bank untukmemungut maupun meminjam dengan bunga atauyang disebut dengan riba, dan suatu larangan investasi bagi beberapa usaha yang dikategorikan haram, di mana hal tersebut tidak bisa dijamin olehperbankan sistem konvensional (Mujahidin, 2016).

Sehingga BI Rate tidak memiliki dampak atas laba (ROA) perbankan syariah, karena pada dasarnya nasabah tidak mengharapkan keuntungan ketika menabung, tetapi nasabah bank syariah yang mengutamakan pada prinsip syariat Islam. Laba yang diperoleh oleh bank syariah bukan dari bunga tabungan saja, melainkan dari jual beli valuta asing (Sharf), pinjaman dari bank untuk nasabah dengan keperluan mendesak (Qardh), mengalihkan utang piutang agar nasabah mendapatkan modal tunai dari bank (Hiwalah), jual beli properti yang dilakukan bank syariah dengan developer dan selanjutnya dijual kepada nasabah (Murabahah), pembiayaan sewa (Ijarah) dan bank syariah merupakan jasa tata laksana administrasi dokumen termasuk giro dan tabungan (Al-Wadiah) (ojk.go.id, 2017).

\section{KESIMPULAN}

Hasil dari uji simultan variabel CAR, NPF, FDR, Inflasi, serta BI Rate mempunyai dampak atas ROA. Pengujian secara individu bahwa terdapat empat variabel yang tidak memiliki pengaruh atas ROA yaitu NPF,FDR, Inflasi, BI Rate. Sementara itu, variabel CAR berdampak positif atas ROA Perbankan Syariah di Indonesia periode 2014 hingga 2018. Penelitian ini diharapkan bisa digunakan sebagai bahan pertimbangan bagi perusahaan perbankan syariah dalam mempertimbangkan faktorfaktor apa saja yang harus dipertimbkan untuk mempertahankan profitabilitas perbankan syariah seperti modal bank dan asset tertimbang rata-rata karena hal ini akan berpengaruh terhadap nilai CAR. Jika nilai CAR naik maka laba perusahaan (ROA) juga ikut meningkat dan begitu sebaliknya. Berdasarkan hasil penelitian dalam memutuskan keputusan investasi, investor perlu mempertimbangkan perusahaan perbankan syariah yang memiliki nilai CAR minimum 8\% berdasarkan ketentuan Bank Indonesia (BI) yang tercantum dalam Peraturan BI N0.13/PBI/2011. 
Penelitian selanjutnya diharapkan menambahkan variabel lain seperti Bank's size (Yusuf, 2017), Thrid party funds (Nuriyah, Endri dan Yasid, 2018) dan Gross Domestic Product (GDP), securities (Aliyu dan Yusof, 2016).

Terdapat beberapa keterbatasan yang ditemukan pada penelitian ini, ialah hasil yang didapatkan kurang jelas yang disebabkan karena terlalu singkatnya periode yang digunakan (5 tahun). Penelitian ini hanya melihat dari faktor ekonomi makro saja. Keterbatasan lainnya yaitu dalam mencari data keuangan pada website perbankan, kemudian ada beberapa data yang tidak lengkap, sehingga data yang lengkap jumlahnya terbatas.

\section{DAFTAR PUSTAKA}

Abduh, M., \& Idrees, Y. Determinants of Islamic Banking Profitability in Malaysia. Australian Journal of Basic and Applied Sciences. 7(2): 204-210. ttps://www.researchgate.net/publication/267642343

Ali, Q., Maamor, S., Yaacob, H., \& Gill, T. U. M. (2018). Impact of Macroeconomic Variables on Islamic Banks Profitability. Journal of Accounting and Applied Business Research. 1(2): 1-16. https://www.researchgate.net/publication/324910815

Aliyu, S., Yusof, M. R. (2016). Profitability and Cost Efficiency of Islamic Banks A Panel Analysis of Some Selected Countries. International Journal of Economics and Financial Issues. 6(4): 1736-1743.

Akhtar, F. M., Ali, K., \& Shaqat, S. (2011). Factors Influencing the Profitability of Islamic Banks of Pakistan. International Research Journal of Finance and Economics. 6(6): 125-132. http://www.eurojournals.com/finance.htm

Amelia, Erika. (2015). Financial Ratio and Its Influence to Profitability in Islamic Banks. Al- Iqtishad. 7(2): 229-240.

Bank Indonesia. (2009). Laporan Kebijakan Moneter. (www.bi.go.id/id/id/publikasi/kebijakanmoneter/tinjauan/Pages/LKM_trw309.aspx. Diakses pada 9 April 2020).

Bank Indonesia. (2013). Laporan Inflasi (Indeks Harga Konsumen). (www.bi.go.id/id/moneter/ inflasi/data/Default.aspx. Diakses pada 9 April 2020).

Bank Muamalat. (2014). Laporankeuangan 2014. (https://www.bankmuamalat.co.id/laporan keuangan/ tahunan/2014/. Diakses pada 3 April 2020).

Bank Victoria syariah. (2014). Laporankeuangan 2014. (https://www.bankvictoriasyariah.co.idlaporan keuangan/tahunan/2014/. Diakses pada 3 April 2020).

Bcasyariah. (2014). Laporan keuangan 2014. (https:///www.bcasyariah.co.id/laporan keuangan/tahunan/2014/. Diakses pada 3 April 2020).

Bnisyariah. (2014). Laporan keuangan 2014. (https://www.bnisyariah.co.id/laporan keuangan/tahunan/2014/. Diakses pada 3 April 2020).

Brigham, F. E., \& Houston, F. J. (2010). Dasar-dasar Manajemen Keuangan. Jakarta Selatan: Salemba Empat.

Brisyariah. (2014). Laporan keuangan 2014. (https://www.brisyariah.co.id/laporan keuangan/tahunan/2014/. Diakses pada 3 April 2020). 
Nanda Nur Aini Fadillah \& R. A. Sista Paramita. Pengaruh CAR, NPF, FDR, Inflasi dan BI Rate terhadap Profitabilitas Perusahaan Perbankan Syariah di Indonesia Periode 2014-2018

Ervani, E. (2010). Analisis Pengaruh Capital Adequacy Ratio, Loan to Deposit Ratio, dan Biaya Operasional Bank terhadap Profitabilitas Bank Go Publik di Indonesia Periode 2000-2007. Jurnal Ekonomi dan Kebijakan. 3(2): 165-171. https://journal.unnes.ac.id/nju/index.php/jejak/article/view/4659

Ghozali. (2016). Aplikasi Analisis Multivariate dengan Program IBM SPSS 23. Semarang: Universitas Diponegoro.

Hakiim, Ningsukma. (2018). Pengaruh Internal Capital Adequacy Ratio (CAR), Financing to Deposit Ratio (FDR), dan Biaya Operasional Per Pendapatan Operasional (BOPO) dalam Peningkatan Profitabilitas Industri Bank Syariah di Indonesia. Jurnal Mega Aktiva. 7(1): 1974-2086. https://megaaktiva.umkendari.ac.id/index.php/Jurnal

Hanania, Luthfia. (2015). Faktor Internal dan Eksternal yang Memengaruhi Profitabilitas Perbankan Syariah dalam Jangka Pendek dan Jangka Panjang. Perbanas Review. 1(1): 151-168.

Hardiyanti, Weka. (2019). Analisis Pengaruh Inflasi, BI Rate, CAR, NPF, dan BOPO Terhadap Profitabilitas Bank Pembiayaan RakyatSyariah di Indonesia Tahun 2013-2017, Skripsi. Surakarta: UMS.

Hidayati, N. A. (2014). Pengaruh Inflasi, BI Rate, dan Kurs Terhadap Profitabilitas Bank Syariah di Indonesia. Ejurnal IAIN Tulung agung. 1(1): 73-97. http://jurnal.stieama.ac.id/index.php/ama/article/view/143

Hosen, N. M., \& Muhari, S. (2017). Indicator of Islamic Banking Competitiveness in the Asean Economic Community Era: Case Study of Indonesia and Malaysia. International Research Journal of Finance and Economic.163(2): 18-35. http://www.internationalresearchjournaloffinanceandeconomics.com

Jogiyanto. (2000). Teori Portifolio dan Investasi Edisi 2. Yogyakarta: Universitas Gajah Mada

Karim, A. A. (2006). Bank Islam: Analisis Fiqih dan Keuangan. Jakarta: PT. Raja Grafindo Persada.

Kinanti, A. R., \& Purwohandoko, M. M. (2018). Influence of Thrid- Party Funds, CAR, NPF and FDR Towards the Return On Assets of Islamic Banks In Indonesia, Journal Research Opinion. 5(11): 2280-2287.http://researchopinion.in/index.php/jro

$\begin{array}{lllllll}\text { Kontan.co.id, } & \text { I. } & \text { (2014). } & \text { BI } & \text { (Reverse) }\end{array}$ (pusatdata.kontan.co.id/makroekonomi/bi_rate. Diakses pada 9 April 2020).

Kontan.co.id, I. (2015). BI 7-day (Reverse) Repo Rate. (pusatdata.kontan.co.id/makroekonomi/bi_rate. Diakses pada 9 April 2020).

Kontan.co.id, I. (2016). BI 7-day (Reverse) Repo Rate. (pusatdata.kontan.co.id/makroekonomi/bi_rate. Diakses pada 9 April 2020).

Kusuma, D. A. (2018). Pengaruh Inflasi, BI Rate, Nilai Tukar Mata Uang, CAR, NPF, dan FDR terhadap Profitabilitas Bank Umum Syariah di Indonesia, Skripsi. Yogyakarta: UII.

Mandirisyariah.co.id. (2014). Laporan keuangan 2014. (https://www.mandirisyariah.co.id/laporan keuangan/tahunan/2014/. Diakses pada 3 April 2020).

Mansur, T. M. (2015). Pengaruh FDR, BOPO dan NPF Terhadap Profitabilitas Bank Umum Syariah Periode 2012-2014. Skripsi. Semarang: UIN. 
Maybank.co.id. (2014). Laporan keuangan 2014. (https://www.maybank.co.id/laporan keuangan/tahunan/2014/. Diakses pada 3 April 2020).

Megasyariah.co.id. (2014). Laporan keuangan 2014. (https://www.megasyariah.co.id/laporan keuangan/tahunan/2014/. Diakses pada 3 April 2020).

Munir, M. (2018). Analisis Pengaruh CAR, NPF, FDR dan Inflasi terhadap Profitabilitas Perbankan Syariah di Indonesia. Jurnal of Islamic Economics, Finance and Banking. 1(1): 89-98. http://journal2.uad.ac.id/index.php/ijiefb/article/view/285

Nuriyah, A. Endri \& Yasid, M. (2018). Micro, Small-Financing and Its Implications on the Profitability of Sharia Banks. DeReMa Jurnal Manajemen. 13(2): 175-197. https://ojs.uph.edu/index.php/DJM/article/view/1054

Ojk.go.id. (2017). Sejarah Perbankan Syariah. https://www.ojk.go.id/id/kanal/syariah/tentangsyariah/Pages/Sejarah-Perbankan-Syariah.aspx\#. Diakses pada 13 Oktober 2019).

Ojk.go.id. https://www.ojk.go.id/id/kanal/syariah/tentangsyariah/Pages/PBS-dan-Kelembagaan.aspx\#. Diakses pada 13 Oktober 2019).

Paninbanksyariah.co.id. 2014.Laporan keuangan 2014. (https://www.paninbanksyariah.co.id/laporan keuangan/tahunan/2014/. Diakses pada 3 April 2020).

Purwohandoko, Nadia Asandimitra, Yuyun Isbanah dan Achmad Kautsar. (2014). Dasar-Dasar Manajemen Keuangan: teori, aplikasi dan kasus. Surabaya: Unesa University Press.

Simatupang, A., \& Franzlay, D. (2016). Capital Adequacy Ratio (CAR), Non Performing Financing (NPF), Efesiensi Operasional (BOPO), dan Financing to Deposit Ratio (FDR) Terhadap Profitabilitas Bank Umum Syariah di Indonesia. Jurnal Administrasi Kantor. 4(2): 466-485. https://www.academia.edu/37715839/Pengaruh_Pembiayaan_UMKM_dan_Rasio_Keuangan_ Terhadap_Pertumbuhan_Laba_Bank_Umum_Syariah_di_Indonesia

Sugiyono. (2017). Metode Penelitian Kuantitatif, Kualitatif dan R\&D. Bandung: Alfabeta.

Sumarlin. (2016). Analisis Pengaruh Inflasi, CAR, FDR dan NPF Terhadap Profitabilitas Perbankan Syariah. Jurnal Ekonomi, Manajemen, dan Akuntansi. 6(2): 296-313. http://journal.uinalauddin.ac.id/index.php/assets/article/view/2910

Sunariyah. (2013). Pengantar Pengetahuan Pasar Modal. Yogyakarta: UPP-STIM YKPN. https://www.kajianpustaka.com/2017/08/return-on-assets-roa.html. Diakses pada 10 Desembem 2019.

Syah, T. A. (2018). Pengaruh Inflasi, BI RATE, NPF, dan BOPO Terhadap Profitabilitas Bank Umum Syariah di Indonesia. Jurnal Ekonomi Islam. 6(1): 133-153.

Syariahbukopin.co.id. (2014). Laporan keuangan 2014. (https://www.syariahbukopin.co.id/laporan keuangan/tahunan/2014/. Diakses pada 3 April 2020).

Wibowo, S. E., \& Syaichu, M. (2013). Analisis Pengaruh Suku Bunga, Inflasi, CAR, BOPO, NPF Terhadap Profitabilitas Bank Syariah. Diponegoro Journal of Accounting. 2(2): 1-10. http://ejournal-s1.undip.ac.id/index.php/djom 
Nanda Nur Aini Fadillah \& R. A. Sista Paramita. Pengaruh CAR, NPF, FDR, Inflasi dan BI Rate terhadap Profitabilitas Perusahaan Perbankan Syariah di Indonesia Periode 2014-2018

Yusuf, M. (2017). Dampak Indikator Rasio Keuangan terhadap Profitabilitas Bank Umum Syariah di Indonesia. Jurnal Keuangan dan Perbankan. 13(2): 141-151. http://journal.ibs.ac.id/index.php/jkp/article/view/53

Zulfiah, A., \& Susilowibowo, Joko. (2014). Pengaruh Inflasi, BI Rate, Capital Adequacy Ratio (CAR), Non Performing Finance (NPF), Biaya Operasional dan Pendapatan Operasional (BOPO) Terhadap Profitabilitas Bank Umum Syariah Periode 2008-2012. Jurnal Ilmu Manajemen. 2(3): 759-770. https://www.academia.edu/35087933/ANA 